\title{
SOLVENCY AND SURVIVAL OF MICROFINANCE INSTITUTIONS: AN INDIAN SCENARIO-POLICY IMPLICATIONS TO IMPROVE ENDURANCE
}

\author{
Dr. S. Sangeetha \\ Associate Professor \\ KCT Business School \\ Kumaraguru College of Technology \\ Saravanampatti, Coimbatore, Tamilnadu, India \\ E-mail: sangisubramanian@gmail.com \\ Dr. K. Chitra \\ Principal \\ Sri Ramakrishna College of Arts and Science for Women \\ 395, Sarojini Naidu Road, Siddhapudur, Coimbatore, India \\ E-mail: profkchitra@gmail.com
}

\begin{abstract}
In India, more than 450 million people are outside banking orbit. Many economically deprived communities borrow money from money lenders who charged them to an extent of $115 \%$ interest. Microfinance was a strong tool to rescue the poor from Ponzi Schemes. Microfinance industry thrived well in India. It recorded huge growth in South India than North India. The Microfinance crisis broke during the year 2010 in Andhra Pradesh. A bill enacted in Andhra Pradesh made the situation still worse. The repayment rate of the Micro finance clients dropped from $95 \%$ (2010) to 1\% (2012). This made the survival of the Microfinance Institutions (MFIs) questionable. The paper aims at exploring the solvency and survival positions of the Private \& Public NBFC MFIs. Based on the Altman's Z revised score model (applicable for financial institutions) and Survival analysis, the results reflect that Private NBFC MFIs are solvent and had better survival than Public NBFC MFIs. It aims at understanding the factors discriminating the solvent and insolvent Microfinance Institutions.
\end{abstract}

Keywords: Indian Microfinance Institutions, Solvency, Bankruptcy Prediction, Default.

JEL Classification Codes: G20, G21, G23, G28, G33.

\section{INTRODUCTION}

The Indian population is about 1000 million with a GDP of 5.4\% during 2014 as per IMF estimates. Of these 300 million people, about 80 million households are classified under the below the poverty line. In India, as per the Tendulkar methodology, people BPL are those who earn per capita of Rs. 816 in rural and Rs. 1000 per month in urban areas. According to World Bank report, people whose earnings are less than one dollar exist in large quantum. Despite eagle eye approach followed by the commercial banks in the rural banking processes, the informal sector still caters to $80 \%$ of the population for credit requirements. An expert panel headed by 
Former Reserve Bank of India (RBI) Governor C. Rangarajan demarcated that the Indian population Below the Poverty Line (BPL) was about 29.5 \% (363 million) during the year 201112, which grew from 270 million the previous year. The poor populace borrowed money from the local moneylenders. They charged higher interest rate to an extent of $115 \%$.

The annual credit requirement of the poor is about Rs. 60000 crores. Microfinance Institutions tend to offer low-cost loans and periodically longer loans. MFIs are becoming best tool in achieving financial inclusion as it turns out to be better formal financial alternative (Jayasheela \& Hans, 2006; Sahai et al., 2020). If the MFIs wish to act under priority lending sector, then they are supposed to provide loans at $26 \%$ and with margin cap of $10 \%$ only. About $80 \%$ of MFIs could lend at this rate. Those which are charging more are termed to be inefficient MFIs and will be called off by RBI's policy. The crisis faced by Indian microfinance institutions is discussed in the forthcoming section.

\section{NEED FOR THE STUDY \& OBJECTIVE}

As the adage goes, only the fittest will survive, many small MFIs must find their own way. As per the RBI officials' suggestions, the MFI should scale up their operations in a proper way understanding their limitations. The role of MFIs will surely gain momentum as the Indian Banking system suffers with huge non-performing assets issues. MFIs may have to bear huge financial expenses as the loan sponsored by the banks is very expensive. Nearly $49 \%$ of the total expenses are borne as financial expense by the MFIs. Other expenses like personnel expense and administrative expenses spare to $25 \%$ and $26 \%$ respectively.

In India, predominantly Microfinance funding was done by NGOs. Later credit union, financial cooperative \& state-owned development and postal savings banks joined the troop. After some time, NABARD the apex development body took the lead of world's largest micro credit initiative in infusing the funds to the people through the SHG Bank Linkage Programme (SHGBLP) catering to more than 11 crore groups, which started initially with just 500 groups two decades before. Majority of those groups are Women groups.

On the contrary, the private institutions, the so-called MFIs (Sec 25 companies and NBFCs) also jumped into the competition of providing funds which led to the commercialisation of the business (Chandrasekhar \& Ghosh, 2012). They generally promoted Joint Liability Group (JLG) parallel with individual loans. Mainly the probability of Women joining the JLG loan contract was much higher (Kundu, 2009).

Introduction to Microfinance Bill by Andhra Pradesh government restricted the lenders in collection of dues (SHGAP). Microfinance Institutions suffered a lot due to delay / default in payments by borrowers. Almost Due to this the survival of the MFIs turned to be questionable. Andhra Pradesh, a South Indian state outnumbered the national average. It ranked first in terms of loan portfolio and outreach. During 2010, client outreach was 31.4 million and the gross loan portfolio level was Rs 207 billion. It recorded 18\% growth rate in client outreach and 56\% in the loan portfolio which was just 13.1\% during 2010-11. Andhra Pradesh crisis started during the year 2006. Government compelled to close 57 branches of two giant MFIs SHARE and Spandana Sphoorty in Krishna District. The government took actions on them for multiple reasons like coercive recovery, usurious interest rates, poor governance and adoption of excessive profiteering methodology. As a part of scale of expansion, double loans were provided to poor with no collateral assets, who failed to repay their outstanding loans due to low income generating capacity. Coercive recovery practices exhibited by the MFIs led to commitment of suicides in the districts of Andhra Pradesh (Ashta et al., 2015). This set a saturation stage for MF 
in the state. The problems which arose out of crisis was intensified further by the political motivation to develop the Pavalavaddi Scheme, an interest subsidy scheme to reduce the financial burden of Self-Help Groups run by the AP government. On an average the MFIs loan debt outstanding per household of pan India remained at Rs.7700, whereas it was Rs.65000 at Andhra Pradesh during the same period. The inability led to 57 suicides in short span. The government came out with AP ordinance bill. Almost all the AP MFIs operations came to standstill. SA-Dhan, Association for MFIs, a national level player took some mutilation mechanism to restore and sustain the operations of MFIs. MFIs were compelled to charge to an extent of 21-24 percent only. They were insisted to follow and enhance good corporate governance. Banking Sector was seriously affected by this crisis. One third of total loan portfolio (Rs.21000 crores) was left unpaid by the MFIs' to the banks. Banks lost the trust on the MFIs. Banks which financed the MFIs, decided not to fund them, as the MFIs Net worth was turning negative. Thereby the MFIs were handicapped and could not issue fresh loans to its clients. Borrowings by MFI became costly. In addendum, the MFIs found it difficult to raise money for the strategic growth. During the year 2011-12, with pressure building up, the Operating Self Sufficiency slashed from 150 percent to 40 percent. In the state of sector report 2012, it was recorded that only 18 percent of MFIs recorded positive ROA ie., 15\%. The Bharat Microfinance Quick Report 2012 - Microfinance - Growing against All Odds reflected the Andhra Pradesh crisis.

One of the major issues faced by the Self-help groups a decade before was coercive collective process by the microfinance Institutional funders. The Andhra Pradesh (AP) Crisis (An Indian State, which was the leader in Microfinance faced a Social crisis, led to regulatory impact on coercive recovery mechanism. The recovery dipped to $15 \%$ during 2011 and again to $1 \%$ in the year 2012. In Andhra Pradesh, banks offered loans at $12 \%$ per annum (1996) which was slashed as part of declared manifesto during state election period. The interest rate was slashed to 9 percent (1999) and later to 3\% (2004). The cost of funds was brought down to zero percent during 2011. The Indian Government planned to offer loans to Self-Help groups across the nation at a very cheaper interest rate. It also proposed to commence Microfinance bank in Andhra Pradesh which would provide loans at 12-14 percent for these Self-Help groups against 26 percent offered by MFIs (Naga Sridhar, 2011). In India, microfinance industry had not been under regulatory radar until the crisis stroked at Andhra Pradesh state MFIs during October 2010. It created a shock wave to the entire Microfinance Industry as a whole. Multiple loans, higher interest rates, Coercive recovery practices lead to self-killing by MFI clients (Kaur, 2016). This gained the attention of the Andhra Pradesh government, which enacted an ordinance bill. This chained the hands of MFIs by introducing changes in collection policy. The Act brought the operations of MFIs to standstill. More than half a million SHGs got linked to banks over the years. But the South India accounted to three-fourth of this figure with Andhra Pradesh as a definite leader. Andhra could mobilize 80 lakh women in fifteen years. Under NABARD scheme of providing loans to SHGs Andhra benefitted a lot, where it consumed 52 percent of loan disbursement by itself. However, in recent times, even the Microfinance industry is facing challenges. The Loan repayment is affected by varied reasons like age of the client, amount of loan received, income level, number of family members, education level, occupation etc. Non repayment of Loan is the biggest risk faced by the MFIs. The collection rate of MFIs in Andhra Pradesh pitched to 5-10 percent. For a microfinance funder, survival and growth are driven by customer satisfaction and commercialisation. To enjoy the benefits, free choices should be provided to clients. Due to commercialisation, beneficiaries have become clients. The impetus 
has shifted from voluminous rapid loan growth (quantity of loans) to more sustainable loan growth (quality of loans). As commercialisation of MFIs' led to multiple loans to individual borrowers, it landed upon non repayment of dues by the customers (Roy, 2011). This led to serious financial crisis for MF in Andhra Pradesh. The growth in Loan dipped to 11.35 percent. Credit Bureau took cautious steps in spotting clients with multiple loans. However, it has not helped to curtail the entire problem, as many are trapped in informal sources which don't come under the periscope of credit bureaus. The temporary regulatory framework drafted to protect the clients has succeeded to a certain extent in reducing the problem. But the problem picked up for the microfinance institutions as the adverse discernments coupled with increased operating cost added fuel to funding mechanisms. During the same period, market structure kept changing as many NGO's got converted into Profit making NBFCs. Few studies state that the Solvency tested through $\mathrm{Z}$ score, highlights that the risks faced by MFIs is like banks (Schulte \& Winkler, 2019). The Solvency scores had impact in return on assets; while non-performing loans is a better measure to analyse the solvency especially for microfinance institutions (Arcalean et al., 2007; Chakravarty \& Pylypiv, 2015; Janardhanan \& Uma, 2020). A study used a Z score model to test the solvency of Indonesian banks which identified distressed banks (Khaddafi et al., 2017). Like traditional banking, microfinance failures led to loss of capital which re-insists the necessity to z-score model (Marulanda et al., 2010). Few studies state that the Survival rate of MFIs could be measured through agility scale which would measure the ability to survive and thrive through variables like responsiveness, adaptability, flexibility, resilience, innovativeness, and compliance (Opinya \& Kwasira, 2015). The solvency of institutions depends more on liability management (Rahman et al., 2021). It becomes essential to estimate whether the Microfinance Institutions can be solvent and would survive healthy to contribute towards financial inclusion. Most of studies focus on Solvency and efficiency and not more on Survival of Microfinance institutions. This paper purely dwells with the objective of analysing the solvency and predicting the longevity of Select NBFC MFIs through survival analysis. It also intends to learn the factors discriminating solvent and insolvent institutions. The research methodology and sample selection process are described in the following section.

\section{Research Design and Sample Selection}

\section{METHOD}

This research aims at understanding the solvency and survival position of the MFIs, thereby it is descriptive and analytical in nature. Multistage Stratified random technique is used which is explained below. Top 5 MFIs in CRISIL ratings of 2011 is taken for the sampling process. NBFC-MFIs were taken into consideration, as they faced a huge credit crisis than other forms. It accounted to 21 NBFC-MFIs. The Amount of loan portfolio and Share accounted to Rs.17907 crores and 86\% respectively. Selection of MFIs is done based on Gross Loan Portfolio (GLP). Higher the Gross Loan Portfolio (GLP), higher will be the probability of the credit risk. MFIN (MFIs Network) Micrometer 2012 listed the MFIs based on loan disbursement and outstanding. The MFIs selected for analysis belong to Portfolio size more than Rs. 500 crores. From the list, top 2 Public NBFC- MFIs and 3 Private NBFC MFIs are taken for analysis. Bandhan, Equitas and SKS are selected under Private NBFC MFIs and Spandana Sphoorty, Share Microfinance Limited (SML) are selected under Public NBFC- MFIs for the analysis. The above mentioned top 5 MFIs were leading players who contribute to 68 percent of the total Microfinance industry in terms of Gross Loan Portfolio and 73 percent in terms of Loan disbursement. The remaining MFIs contributes to very small quantum. Hence the top five are selected as representative 
sample. In this, $80 \%$ of large MFIs with Loan Size above Rs. 500 crores are in Southern region of India and 50\% of MFIs are located exclusively in Andhra Pradesh.

\section{Source of Data \& Data Collection and Scaling Technique}

The relevant 10-year data up to 2013 is taken for analysis from the Mix (Microfinance Information Exchange) market, Annual reports, Financial Statements, Company website, Financial Projections, Company profile and MFIN. Further as the microfinance industry underwent deep changes. many MFIs got changed in its form, structure as well some turned into universal/ commercial banks and some into small finance banks \& payment banks. Thereby the data after 2013 may not suit the researcher requirements. Secondary data was used to measure the Solvency and Survival positions of MFIs.

\section{Research Tool}

\section{Altman Z Score Model 4}

The Altman Z score model revised version 4 (2000) is applicable for banks and financial institutions. (Sharma, 2013; Krishna Chaitanya, 2005). Solvency risk speaks on the capital strength of the financial Institutions. Adequate amount of equity measured through the equity to total assets, allows the institutions to absorb shocks. Higher the capitalization, lower the insolvency risks. Lack of Liquidity will lead to insolvency. In Business Bankruptcy prediction model of Altman's suggests revised Z score (Anjum, 2012) with 5 ratios namely X1-Working capital / Total assets (0.717); X2 - Retained Earnings / Total assets (0.847); X3 - EBIT / Total assets (3.107); X4 - Net worth (book value) / Total liabilities (0.420); X5 - Sales / Total assets (0.998), which helps prediction of insolvency in advance. It also suggests Revised Model for non-manufacturing companies as X1 - Working capital / Total assets (6.56); X2 - Retained Earnings / Total assets (3.26); X3 - EBIT / Total assets (6.72); X4 - Net worth (book value) / Total liabilities (1.05). The Altman's Z score model is used to analyse the Solvency of firms. The researcher has used Altman's revised model 4 meant for Non-Manufacturing Institutions. This model uses 4 ratios instead of 5 namely Working Capital / Total Assets, Retained Earnings / Total Assets, EBIT / Total Assets, Net Worth (Book Value) / Total Liabilities with weights 6.56, $3.26,6.72$ and 1.05 respectively. If the scores are above 2.6 , they are healthy companies, if it ranges between 1.1 to 2.6 , they are in gray areas, scores below that means those companies turn out to be bankrupt.

Survival Analysis (SA) is used to predict the event occurrence. The dependent variable has 2 portions survival and hazard function. The survival function explains the probability of survival or solvency up to a specified duration. The hazard function explains the event of insolvency of the corporate within a stipulated period. SA is used to test the future growth of the MFIs. It describes the proportion of population that will survive or die. It's otherwise called as duration modeling in economics. In the survival chart, each drop down shows an event happening. The event is the chance of the company becoming an insolvent. Cross sign shows the censored event (survival chance). (One is event occurred, zero is survival or censored event). SPSS is used to perform Survival Analysis. 


\section{RESULTS \& DISCUSSIONS}

Table1. Percentage of Solvency position throughout the study period and cumulative ranking based on weighted average solvency scores.

\begin{tabular}{|l|c|c|c|c|c|}
\hline \multicolumn{1}{|c|}{ MFIS } & $\begin{array}{c}\text { BANKRUPT } \\
\mathbf{( 1 ) \%}\end{array}$ & $\begin{array}{c}\text { GRAY } \\
\text { AREAS } \\
\mathbf{( 2 ) \%}\end{array}$ & $\begin{array}{c}\text { NOT } \\
\text { BANKRUPT } \\
\mathbf{( 3 ) \%}\end{array}$ & $\begin{array}{c}\text { Weighted average } \\
\text { Solvency levels }\end{array}$ & $\begin{array}{c}\text { Cumulative } \\
\text { Rank }\end{array}$ \\
\hline SKS & 20 & 10 & 70 & 2.5 & 1 \\
\hline BANDHAN & 40 & 30 & 30 & 2.16 & 3 \\
\hline SPANDANA & 70 & 20 & 10 & 1.9 & 4 \\
\hline SHARE & 70 & 20 & 10 & 1.4 & 5 \\
\hline EQUITAS & 17 & 50 & 33 & 1.4 & 2 \\
\hline
\end{tabular}

\section{Solvency Position}

Table 1 shows the solvency position of the respondent companies for the study period. Altman's Multi Discriminant Analysis- Solvency Models version 4 was used and their weightage for each variable had been identified. Version model 3 was also executed which showed the solvency positions of the 5 companies were not in appreciable condition. SKS was not bankrupt during the years 2009-2011, but still they were not free from solvency issues. In other years it appeared to be insolvent. Bandhan and Spandana Sphoorty also did not satisfy the solvency grades and deemed to be insolvent. The results look similar for SHARE and EQUITAS too. Bandhan was offered in principle approval to operate as a bank by Reserve Bank of India, India's Central bank. The researcher felt that the company which is deemed to be insolvent cannot be offered to be a bank thereby attempts to implement revised model 4 to check for its solvency position.

Altman's revised model 4 shows that SKS has tough times during the last 2 years. Bandhan had struggled during the beginning years and Spandana Sphoorty had a mixed fortunes and tough times. SHARE was bankrupt in 2008-09. For EQUITAS, the situation is bit promising than other MFIs as it shows the lower solvency position only in the first year, after which the situation has kept improving only. Altman's revised model 4 results provides 90.9 percent success of predicting the bankruptcy of the firm one year in advance and 97 percent accuracy of nonbankruptcy.

Table 1 shows the proportion of being bankrupt by the respondent companies. The last 2 years seems to be a bankrupt situation for SKS proven by both models. SKS microfinance had been the most affected MFI after the AP Crisis. The trends were promising until 2010. 70 percent of its life span during the study period had been with good solvency position and 20 percent was bankrupt and 10 percent was under gray area. Bandhan did not have a promising scenario under both methods, especially the starting years. Interestingly Bandhan was under either gray or nonbankrupt scene during and after AP Crisis. Even Bandhan is Bankrupt during 40 percent of the study period and could maintain good solvency position only during 30 percent of the study period. Spandana Sphoorty is bankrupt in 70 percent of the study period and had been at good stake for 10 percent only. SHARE is bankrupt for 70 percent of the study period. EQUITAS with just $17 \%$ shows the strong solvency position over the years. Altman Model helps to identify MFIs solvency position. The results of Altman's Z Score model showed that few of MFIs are solvent and few are not and mostly the private one were much efficient than the public NBFC 
(Youssef, 2018). To identify the factor that discriminates the solvent and insolvent MFIs, MDA is performed. 10 variables are taken to classify the MFIs into Solvent and Insolvent which was used as an input for Survival analysis.

\section{Survival Positions of Microfinance Institutions Over A Period Using Survival Analysis}

Solvency position refers the ability of the firm to cover the fixed cost in longer run. Survival analysis refers to long term continued healthy existence of the firm. Altman $\mathrm{Z}$ score model was performed, and the scores had been analysed. For the survival analysis, the bankrupt years are zero and other years are coded as one. Kaplan Meier's survival analysis is performed using SPSS. The solvent scores are zero and the insolvent is taken as one. Three items are taken into consideration. The researcher has considered the first-year value as 12 months, 2nd year as 24 months etc for 10 years). The SKS was assigned as 1, Bandhan as 2, Spandana Sphoorty as 3, SHARE as 4 and Equitas as 5. Solvency position of each year is considered for analysis.

\section{Hypothesis Tested}

Null Hypothesis: There is no significant difference between the survival positions of Microfinance Financial Institutions over a period.

Table 2. Survival positions of Microfinance Institutions over a period

Kaplan-Meier Overall Comparisons

\begin{tabular}{|l|c|c|c|}
\hline & Chi-Square & df & Sig. \\
\hline Log Rank (Mantel-Cox) & 9.370 & 4 & .052 \\
\hline Breslow (Generalized Wilcoxon) & 13.025 & 4 & .011 \\
\hline Tarone-Ware & 11.425 & 4 & .022 \\
\hline
\end{tabular}

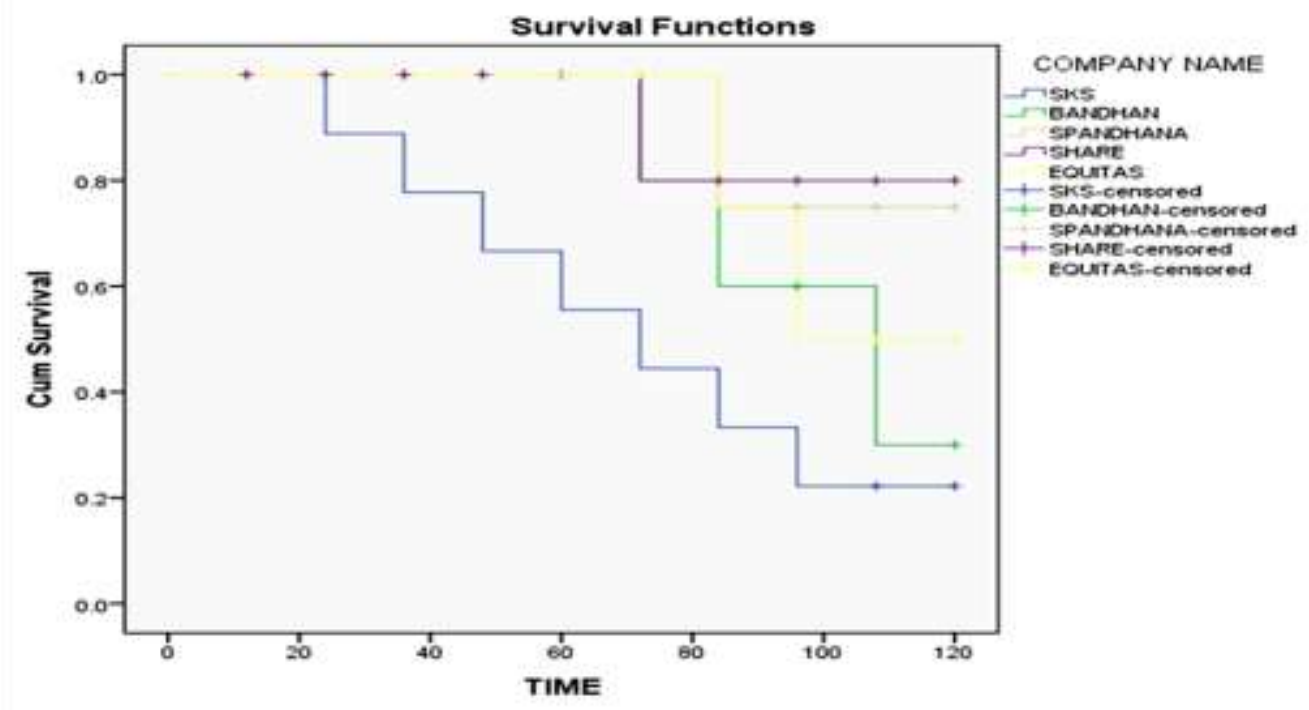

Figure 1. Survival analysis of select Indian Microfinance Institutions

The each drop down in the chart shows an event happening. The event is the chance of the company becoming insolvent. Cross sign shows the censored event (survival chance). (1 is event 
occurred; 0 is survival or censored event). SKS seems to be much volatile slightly picking stability in the last 24 months and the values started to approach the stronger values (close to zero). SHARE is riskier than other MFIs' as the values are closer to one. As the Log Rank (Mantel-Cox) Breslow (Generalized Wilcoxon) and Tarone-Ware are significant ( $\mathrm{p}$ value is greater than $5 \%$ significance) the null hypothesis is hence rejected. (There is a significant difference between the survival curves of the MFIs' over a period). The results show that public NBFC MFIs SHARE and Spandana Sphoorty are still closer to 1 which means they are facing solvency risk whereas for the SKS, Bandhan and EQUITAS the values are below 0.5 and sometimes 0.3 too which meant they are closer to zero i.e. Solvency Score. In spite of the issues faced by the MFIs' they are finding the best means to improve their future operations. It seems the existing scenario will persist in future manoeuvres too.

Table 3. Factors discriminating the solvency position of MFIS.

Hypothesis: There are no significant discriminating factors determining solvency position of firms.

\begin{tabular}{|l|c|c|c|c|c|}
\hline Tests of Equality of Group Means & Wilks' Lambda & $\mathrm{F}$ & $\mathrm{df1}$ & $\mathrm{df2}$ & Sig. \\
\hline Portfolio at Risk & .890 & 5.413 & 1 & 44 & .025 \\
\hline Write Off & .994 & .275 & 1 & 44 & .602 \\
\hline GLP & .967 & 1.509 & 1 & 44 & .226 \\
\hline Loss Reserves & .831 & 8.923 & 1 & 44 & .005 \\
\hline ROAA & .851 & 7.715 & 1 & 44 & .008 \\
\hline Operating Efficiency & .983 & .750 & 1 & 44 & .391 \\
\hline Productivity & .959 & 1.875 & 1 & 44 & .178 \\
\hline ALM & .980 & .901 & 1 & 44 & .348 \\
\hline Liquidity & .781 & 12.352 & 1 & 44 & .001 \\
\hline
\end{tabular}

Based on the reviews made, the following discriminating variables were identified and tested for solvency position of firms. Portfolio at Risk, Write-off, Gross loan portfolio, Loss reserves, Sustainability, Return of average assets, Operating efficiency, Productivity, Asset liability Management and Liquidity. The solvency group is more significant than the insolvent group. Portfolio at Risk, Loss Reserves, Return on Average Assets (ROAA) and Liquidity is significant in predicting variables. Among the four predictive variables, Liquidity and Loss Reserves are more significant than other variables. The strength of relationship of predictor variables and solvency position is 0.664 . The Wilks Lamda value shows that the model is fit. The structure matrix shows that Liquidity \& Loss Reserves which are internal factors that are the best discriminating function coefficients and correlation between variables (Tanwar et al., 2020).

\section{FINDINGS AND SUGGESTIONS}

The survival analysis shows that the future of the MFIs. It is used to test the future growth of the MFIs. It describes a proportion of MFIs that may survive or die. It also reflects the same scenario as that of solvency position, that the Public NBFC-MFIs' future is much dull. SHARE and Spandana Sphoorty are still closer to 1 which denotes that they are under the pressure of solvency risk. Whereas for the private NBFC-MFIs SKS, Bandhan and EQUITAS the values are below $0.5 \& 0.3$ which means there are closer to zero i.e. Solvency Score. Despite the issues 
faced by the MFIs' they find the best means to improve in their future operations. Among the public NBFC MFI and Private NBFC MFI, private institutions perform better than public NBFC MFI. The AP based MFIs survival shows that they are much risk prone in nature. In later years, it is proved that Bandhan turned to a Universal bank (2015) and Equitas as small finance bank (2016) due to its good credentials. SKS merged with IndusInd bank. The long-term solvency is questionable. This model highlights better model to predict the longevity of financial institutions and the scenario is getting reflected in recent times. Survival analysis reflects the scenario in a much better way.

\section{RESEARCH IMPLICATIONS}

Among the public NBFC MFI and Private NBFC MFI, private institutions perform betterthan public NBFC MFI. The AP based MFIs survival shows that they are much risk prone in nature. The long-term solvency is questionable. As stated earlier the model highlights proper audit ensuring the compatibility of objective with the business model. The solvency position of the private NBFCs better than public NBFC MFIs. The public NBFC MFIs should concentrate on Portfolio at Risk, Loss Reserves, Return on Average Assets (ROAA) and Liquidity inorder sustain the solvency position. The regulators should strengthen the regulations specially on lending and collection process to contain further incidences on suicide epidemic. The survival analysis clearly helps to understand the long-term health and future of the MFIs. Thereby suggesting the MFIs/ financial institutions to utilise the Survival analysis as a tool to predict the long-term health of their concern. The government should ensure as well create credit ambience, creation of strong laws toensure that the poor are not ransacked by the Financial institutions at large.

\section{CONCLUSION}

The future of MFIs depends on the current performance and must be challenged to scale on operations, sustainability and cost (Thorat, 2006). The MFIs need to concentrate on solvency position to have better profitability and future. Adoption of better financing techniques and products suitable for market requirement can make the difference. MFIs concentrate on financing poor, chances for exploitation are high, thereby proper regulation and supervision would help in compliance part and the MFIs may not deviate from set norms (Cull et al., 2011; Sangwan \& Nayak, 2020). Enforcing proficiency among the players become much essential (Basu \& Srivastava, 2005). Achievement of poverty alleviation is possible through engagement in small business ventures or minor economic activities (Samer et al., 2015), Proper promotion of productive economic activities among borrowers coupled with the capacity building training programmes would eventually guarantee the profitability and survival of the Microfinance organisations. Concentration on the solvency variables by the Institutions will help in their sustenance as well serve the deprived community in most productive way.

\section{REFERENCES}

Arcalean, C., Calvo-Gonzalez, O., More, C., Van Rixtel, A., Winkler, A., \& Zumer, T. (2007). The causes and nature of the rapid growth of bank credit in the central, eastern and south-eastern European countries. In Rapid Credit Growth in Central and Eastern Europe (pp. 13-46). Palgrave Macmillan, London.

Ashta, A., Khan, S., \& Otto, P. (2015). Does Microfinance Cause or Reduce Suicides? Policy Recommendations for Reducing Borrower Stress. Strategic Change, 24(2), 165-190. 
Anjum, S. (2012). Business Bankruptcy prediction model: A significant study of Altman's Z score. Business Bankruptcy prediction model: A significant study of Altman's Z Score Asian Journal of management research, 3(1), 212-219.

Basu, P., \& Srivastava, P. (2005). Scaling-up Microfinance for India’s Rural Poor, World Bank Policy Research Working Paper - 3646, 1-32.

Chakravarty, S., \& Pylypiv, M. I. (2015). The role of subsidization and organizational status on microfinance borrower repayment rates. World Development, 66, 737-748.

Chandrasekhar, C.P. \& Ghosh, J. (2012). Whatever happened to microfinance?. Retrieved from http://www.thehindubusinessline. com/ opinion/ columns/c-p-chandrasekhar/whateverhappened-to-microfinance/ article 3907679.ece

Cull, R., Demirgüç-Kunt, A., \& Morduch, J. (2011). Does regulatory supervision curtail microfinance profitability and outreach?. World Development, 39(6), 949-965.

Janardhanan, A. K., \& Uma, V. R. (2020). The role of internal control and firm-specific characteristics on firm value: Evidence from Indian financial services sector. Indian Journal of Finance and Banking, 4(1), 117-133.

Jayasheela, D. P., \& Hans, V. B. (2006). Financial Inclusion and Micro-Finance in India: An Overview. Electronic copy available at: http://ssrn. com/abstract, 1089680

Krishna Chaitanya, V. (2005). Measuring Financial Distress of IDBI Using Altman Z-Score Model. The ICFAI Journal of Bank Management, August, 4(3), 7-17.

Kundu, A. (2009). Choice between Microfinance Systems Operating on the Basis of Individual Liability Loan Contract or through Joint Liability Loan', Microfinance Review, 1(1), 1431.

Khaddafi, M., Falahuddin, F., Heikal, M., \& Nandari, A. (2017). Analysis Z-score to predict bankruptcy in banks listed in Indonesia stock exchange. International Journal of Economics and Financial Issues, 7(3), 326.

Kaur, P. (2016). Efficiency of microfinance institutions in India: are they reaching the poorest of the poor?. Vision: The Journal of Business Perspective, 20(1), 54-65.

Marulanda, B., Fajury, L., Paredes, M., \& Gomez, F. (2010). Taking the good from the bad in microfinance: lessons learned from failed experiences in Latin America. San Jose, Costa Rica: Calmeadow Foundation.

Opinya, J. N., \& Kwasira, J. (2015). An Assessment of the Survival Strategies Adopted by Microfinance Institutions in Nakuru Town, Kenya, International Journal Of Innovative Research \& Development, 4(5), 99-104. Retrieved from http://52.172.159.94/index.php/ijird/article/viewFile/70544/55193 
Rahman, S. M. K., Islam, M. K., \& Hossain, M. M. (2021). Leverage induced financial distress of manufacturing firms in Bangladesh: a comparison between listed MNCs and domestic firms by applying Altman's Z score model. Indian Journal of Finance and Banking, 5(2), 28-43. https://doi.org/10.46281/ijfb.v5i2.1006

Roy, S. (2011). Microfinance in India: An Overview of Microfinance and SWOT Analysis of Microfinance (January 25, 2011). http://dx.doi.org/10.2139/ssrn.1747874

Schulte, M., \& Winkler, A. (2019). Drivers of solvency risk-Are microfinance institutions different?. Journal of Banking \& Finance, 106, 403-426.

Sharma, N. (2013). Altman model and financial soundness of Indian banks. International Journal of Accounting and Finance, 3(2), 55-60.

Samer, S., Majid, I., Rizal, S., Muhamad, M. R., \& Rashid, N. (2015). The impact of microfinance on poverty reduction: Empirical evidence from Malaysian perspective. Procedia - Social and Behavioral Sciences, 195, 721-728. https://doi.org/10.1016/j.sbspro.2015.06.343

Sangwan, S., \& Nayak, N. C. (2020). Outreaching the poor under microfinance institutions in India: Rhetoric versus realities. Journal of Public Affairs, 20(4), e2161.

Sahai, S., Sinha Ray, R., \& Tapasvi, S. K. (2020). Why Private Sector Led Financial Inclusion Cannot Work for Development? Case of Micro Credit in India. Indian Journal of Finance and Banking, 4(1), 14-19. https://doi.org/10.46281/ijfb.v4i1.482

Thorat, Y. S. P. (2006). Microfinance in India; Sectoral issues and challenges. Towards a sustainable microfinance outreach in India, 27-42.

Tanwar, J., Seth, H., Vaish, A. K., \& Rao, N. V. M. (2020). Revisiting the Efficiency of Indian Banking Sector: An Analysis of Comparative Models Through Data Envelopment Analysis. Indian Journal of Finance and Banking, 4(1), 92-108. https://doi.org/10.46281/ijfb.v4i1.585

Youssef, A. B. (2018). Migration Analysis of Credit Risk in Tunisian Banking Sector. Indian Journal of Finance and Banking, 2(1), 34-43. https://doi.org/10.46281/ijfb.v2i1.91

\section{Copyrights}

Copyright for this article is retained by the author(s), with first publication rights granted to the journal. This is an open-access article distributed under the terms and conditions of the Creative Commons Attribution license (http://creativecommons.org/licenses/by/4.0/) 